\title{
The Unmaking of Marx's Capital Heinrich's Attempt to Eliminate Marx's Crisis Theory
}

by

Andrew Kliman, Alan Freeman, Nick Potts, Alexey Gusev, and Brendan Cooney ${ }^{1}$

First (July 22, 2013) version.

${ }^{1}$ Authors' affiliations: Pace University,New York, U.S. (Kliman); London Metropolitan University, London, UK (Freeman); Southampton Solent University, Southampton, UK (Potts); Higher School of Economics, Moscow, Russia (Gusev); and kapitalism101.wordpress.com (Cooney). Please address correspondence to Andrew Kliman, akliman@ pace.edu. 


\begin{abstract}
Michael Heinrich's recent Monthly Review article claims that the law of the tendential fall in the rate of profit (LTFRP) was not proved by Marx and cannot be proved. Heinrich also argues that Marx had doubts about the law and that, for this and other other reasons, his theory of capitalist economic crisis was only provisional and more or less in continual flux.

This response shows that Heinrich's elementary misunderstanding of the law-his belief that it is meant to predict what must inevitably happen rather than to explain what does happen-is the source of his charge that it is unproved. It then shows that a simple misreading of Marx's text lies at the basis of Heinrich's claim that the simplest version of the LTFRP, "the law as such," is a failure. Marx's argument that increases in the rate of surplus-value cannot "cancel" the fall in the rate of profit is then defended against Heinrich's attempt to refute it. Finally, the paper presents evidence that Marx was indeed convinced that the LTFRP is correct and that he regarded the crisis theory of volume 3 of Capital as finished in a theoretical sense.
\end{abstract}




\section{Introduction}

As of this writing, we are in the seventh year of the economic crisis into which the U.S. and European economies plunged following the 2007 financial crisis. According to almost all influential canons of economics, this was not supposed to happen. Even mainstream economists admit that they did not anticipate it, and they are increasingly forced to recognize that they still cannot explain it. ${ }^{1}$

If these failures were limited to the mainstream, we would expect a new generation of radicals to turn rapidly to alternative accounts of economic reality. However, this has not occurred. One important reason why it has not is that a large number of radical economists also engaged in triumphalist predictions, insisting - until the crisis broke out - that capitalism was on a new long-term expansionary path. For example, in their recent book The Crisis of Neoliberalism, prominent Marxist economists Gérard Duménil and Dominique Lévy (2011) begin by admitting that

when our book Capital Resurgent: Roots of the Neoliberal Revolution was published by Harvard University Press [in 2004, the neoliberal] strategy appeared successful ... The contemporary crisis is an outcome of the contradictions inherent in that strategy. The crisis revealed the strategy's unsustainable character.

The rest of Duménil and Lévy's book is an attempt to account for the crisis-but on the basis of the same theoretical framework that originally led them to conclude that capitalism was resurgent. What confidence can anyone place in this and other theories that failed to recognize the unsustainable character of the "neoliberal" boom, until the very moment when it descended into a new crisis?

Despite radical economists' lack of theoretical self-criticism, some radical activists are nevertheless turning to the ideas of Karl Marx, capitalism's most consistent critic, even though these ideas have been rejected and dismissed not only by the mainstream but many who present themselves as Marxists. The new generation needs to appraise, without prejudice, whether and how Marx's theory can help them understand this crisis.

The appearance at this moment of Michael Heinrich's (2013) "Crisis Theory, the Law of the Tendency of the Profit Rate to Fall, and Marx's Studies in the 1870s" could have contributed to this much needed clarification, since Heinrich claims to base his presentation-unlike many Marxist scholars-on Marx's own writings. Unfortunately, it is particularly unhelpful, since it doesn't actually clarify Marx's thinking; instead, it is the latest in a long series of efforts to construct what Freeman (2010) has called "Marxism without Marx."

The point of such efforts is to have one's cake and eat it too-to disagree with Marx and put forward an alternative theory, but, at the same time, to present oneself as Marx's successor. This tactic works as follows. The proponents of Marxism without Marx claim to show that his theories are untenable-logically inconsistent, inadequate, or just plain unworthy of consideration - in their original form. This enables them to represent their own works as corrected or improved versions of Marx rather than as the divergent theories that they really are. 
We find this tactic objectionable not because we are opposed to a multiplicity of different theories contesting with one another, but because we firmly support it. What is objectionable is the attempt to make Marx's own theories disappear by replacing them with one's own theory, instead of letting both contend. This is actually a religious method; it is designed to frustrate theoretical controversy by ruling legitimate alternatives out of order. A scientific approach should examine all alternative explanations of reality including Marx's own. It is increasingly apparent that a less-than-scholarly motive is involved: were the theories of the Marxists without Marx actually compared to his, as alternative explanations of the present crisis, their shortcomings would be a great deal clearer.

Heinrich revives this tactic, but with two modifications. First, he claims to show not only that Marx's theory of capitalist crisis is untenable, but also that it isn't really a theory at all; Marx left us no more than "various fragmentary references to crisis theory" (as Heinrich's editors put it in their introductory note). Second, and notably, Heinrich doesn't put forward an alternative crisis theory of his own.

How could it advance our understanding of the crisis to demolish Marx's theory without providing an alternative? The answer is supplied by the editors of Monthly Review. The publication of Heinrich's article, in a journal which has until now disregarded and even looked askance at serious exegetical study of Marx's ideas, has to be set in the context of a theoretical project: to resuscitate the implausible theory set out in Paul A. Baran and Paul Marlor Sweezy's (1966) Monopoly Capital. As the editors state in their introduction,

The development of crisis theory within the Marxian tradition has been central to much of our work in the last several years. The view that the various fragmentary references to crisis theory in the three volumes of Capital constitute a fully developed coherent structure, which only requires diligent exegesis, is a view that has never seemed sensible to us.

Recent research into the evolution of Marx's manuscripts ... has confirmed our understanding in a very exciting way.

It is quite true that "diligent exegesis" cannot create a crisis theory out of mere fragmentary references. It is also true that Heinrich's exegesis (which, we will show, is less than diligent) cannot eliminate the crisis theory rooted in the law of the tendential fall in the rate of profit (LTFRP) and the development of its internal contradictions, because its existence is not an exegetical matter. Even if we assume for the sake of argument that Marx's own thinking about capitalist crisis was unsettled, as Heinrich and Monthly Review claim, it is an incontrovertible fact that this theory exists. We are proponents of it.

In our view, the theory explains the present crisis is a way that is both scientifically legitimate and considerably better than the alternatives currently on offer from the Marxist left. A central mechanism of today's economic crisis is the fact that the rate of profit in the U.S., UK and several other advanced capitalist countries is now falling, and has been falling since the early years of the postwar boom. The theory explains the cause of this fact: the accumulation of 
invested capital has outstripped the growth of employment, which tends to depress the rate of profit; and the various "counteracting factors" have failed to offset this tendency over any but short periods. ${ }^{2}$

Nothing in Heinrich's article calls into question either the existence of this theory or the explanatory power we claim for it. He avoids these issues entirely.

The joint aim of Heinrich and the Monthly Review editors is, instead, to disqualify the theory by "proving" that the LTFRP was not proven by Marx and cannot be proven. The central thesis of our response is that this attempt to disqualify the LTFRP fails because it rests on an elementary misunderstanding of what the law is about and what Marx sought to do by means of it.

The Anglophone public is often intimidated by the pronouncements of German Marx scholars, particularly those that refer to the new Marx-Engels-Gesamtausgabe, which is lamentably inaccessible to the Anglophone public for linguistic or physical reasons. For this reason, our critique of Heinrich's article focuses on its adequacy as an exegetical interpretation of Marx's texts. Familiarity with Marx's unpublished writings is important, but a proper evaluation of an exegetical interpretation must still be based on the adequacy of its interpretive evidence and arguments. We intend to show that Heinrich's article is seriously wanting.

Our argument will proceed as follows:

- Section II will argue that Heinrich's claim that Marx failed to prove the LTFRP is rooted in his mistaken belief that the law is an assertion that the rate of profit must, under all circumstances, fall in the long run. In fact, however, the law is not a prediction of what must inevitably happen, but an explanation of what does happen; it explains why the rate of profit does tend to fall in the long run. By demanding a proof of inevitability, Heinrich makes a scientifically unacceptable demand: that Marx should provide a proof of a false statement.

- Section III will discuss his claim that the simplest version of the LTFRP ("the law as such") is a failure. This claim is rooted in his denial that all increases in the rate of surplus-value (rate of exploitation) are "counteracting factors" to the law as such. We will show that he has simply misread Marx's text. In addition, we will challenge his attempt to refute Marx's argument that increases in the rate of surplus-value cannot "cancel" the fall in the rate of profit. Heinrich's attempted refutation is invalid because it presumes that capital is dis-accumulated and thereby violates a crucial premise of the LTFRP.

- Section IV will challenge the repeated suggestions, by Heinrich and by the editors of Monthly Review, that Marx's theory of capitalist crisis was only provisional and more or less in continual flux. In particular, while Heinrich claims to show that Marx had doubts about the LTFRP, we will present evidence that he was convinced that the law is correct and that he regarded the crisis theory of volume 3 of Capital as finished in a theoretical sense. 


\section{The LTFRP: Assertion of Inevitability or Explanation of Actual Phenomenon?}

A. Heinrich's primary interpretive confusion is introduced by attributing to Marx a claim that does not appear in Marx's text. "However," Heinrich states, "in the long term, according to Marx's thesis, the rate of profit must fall" (emphasis added). ${ }^{3}$ He supplies no citation here, and Marx's text does not support his claim. In particular, the following statement directly contradicts it: "The law operates therefore simply as a tendency, whose effect is decisive only under particular circumstances and over long periods" (Marx 1991a, p. 346, emphasis added).

There are only two statements in the part of volume 3 devoted to the LTFRP that seem somewhat similar to what Heinrich has written. In one case, Marx (1991a, p. 337, emphasis added) writes, "In practice, however, the rate of profit will fall in the long run, as we have seen" (Aber in Wirklichkeit wird die Profitrate, wie bereits gesehn, auf die Dauer fallen). The statement that it "will fall" is not the same as the theoretical claim that it "must fall." This difference is crucial, because Heinrich's pronouncement that the LTFRP is a "failure" is based on Marx's "failure" to prove that the rate of profit must fall. But since Marx made no such claim, the absence of a proof does not constitute a failure.

The other statement of Marx's (1991a, p. 319) that is somewhat similar to Heinrich's version is, "the rate of profit ... must therefore steadily fall." This statement includes the word "must," but it is contained in Marx's initial presentation of "the law itself," which holds the rate of surplusvalue constant. Thus, Marx is simply saying that if constant capital increases faster than variable capital, while the rate of surplus-value is unchanged, then the rate of profit must steadily fall. This is a simple and unexceptionable mathematical deduction from his value theory, not a claim about what must actually occur in the long run.

B. Heinrich's mistaken belief that Marx sought to prove that the rate of profit must fall in the long run, under all circumstances, is intimately bound up with his failure to understand the purpose and function of the LTFRP. He notes correctly that

[t]he idea that the social average rate of profit declines over the long term was considered an empirically confirmed fact since the eighteenth century. Adam Smith and David Ricardo both attempted to demonstrate that the observed fall in the rate of profit was not simply a temporary phenomenon, but rather a result of the inner laws of the development of capitalism. [emphasis added]

However, he then makes a seemingly trivial mistake that is actually of crucial significance:

Marx was not the first to assert a long-term fall in the rate of profit as a result of the inner laws of capitalism. However, he did claim to be the first to have discovered a coherent explanation for this law. [emphases added]

Note that Heinrich contrasts the law to the explanation for it. For Marx, however, the law is the explanation. It explains the "empirically confirmed fact" that the rate of profit does fall ("over long periods" and "under particular circumstances" (Marx 1991a, p. 346)): 
Simple as the law appears from the above arguments, not one of the previous writers on economics succeeded in discovering it, as we shall see later on. These economists perceived the phenomenon, but tortured themselves with their contradictory attempts to explain it. And given the great importance that this law has for capitalist production, one might well say that it forms the mystery around whose solution the whole of political economy since Adam Smith revolves and that the difference between the various schools since Adam Smith consists in the different attempts made to solve it. ... political economy has never found this puzzle's solution. [Marx 1991a, pp. 319-20, emphases added]

Marx claims credit for having discovered the law, even though the economists "perceived the phenomenon," because he was the first to solve the mystery/puzzle, i.e. to successfully explain why the rate of profit tends to fall in the long run. He does not claim credit for discovering the phenomenon of a falling rate of profit. Nor does he claim (here or elsewhere) to have proved that the rate of profit must fall in the long run.

Shortly after contrasting the law to Marx's "explanation for this law," Heinrich briefly gets the law right, equating the law and the explanation: "The 'law' claims that a fall in the rate of profit results in the long-term from the capitalist mode of development of the forces of production." Notice that this statement does not say that the rate of profit must fall in the long run. It says that the capitalist mode of development of the forces of production-accumulation of capital accompanied by labour-saving technical change that increases productivity-is the dominant cause, in the long run, of the fall in the rate of profit. This is indeed Marx's explanation, Marx's law. The rate of profit falls only under particular circumstances, and it can fall for other reasons, such as rising wage rates (Marx 1991a, p. 346, p. 347), but if and when it does exhibit a longterm decline, the capitalist mode of development of the forces of production is the dominant cause of that decline.

However, given Heinrich's preoccupation with Marx's "failure" to prove the proposition that the rate of profit must fall in the long run-with absolute certainty, come what may-it is clear that it is this proposition that he is referring to when he declares the law a failure. But this proposition is not Marx's law. It is not an explanation of an actual phenomenon.

Thus, Heinrich simply does not understand what the LTFRP is or what Marx is trying to prove. As a result, he is in no position to evaluate the law's success or failure. Because he misconstrues the law as an assertion that the rate of profit must fall, he demands proof of this assertion and he triumphantly declares that the LTFRP is a failure since the assertion cannot be "proven."5 However, once one does understand what the LTFRP actually is and what Marx was actually trying to prove - the ability of his value theory, together with his theory of capitalist accumulation, to explain "an empirically confirmed fact"-it becomes clear that Heinrich's demand for proof and his declaration that the LTFRP is a failure are ludicrous.

Consider another law that explains a phenomenon, the law of gravitation. It explains why and how bodies tend to move toward one another. But if Heinrich were a physicist, he would publish an article in the Monthly Physical Review, accompanied by an endorsement by the journal's editors, which tells us that the law of gravitation is instead an assertion that bodies must move 
toward one another, come what may. He would demand that this assertion be proven, after which he would point to the fact that the moon orbits the earth instead of crashing into it and thereby demonstrate that the assertion cannot be proven. And then he would triumphantly declare that the law of gravitation is a failure.

But the actual failure would be Heinrich's failure to understand what the law of gravitation is and what Newton was trying to prove. The fact that the moon orbits the earth does not invalidate the law of gravitation, because the law doesn't assert that bodies must move toward one another, come what may. It explains why they do so if and when they do so. In the same manner, the fact that the laws of mathematics and logic do not rule out cases in which the rate of profit rises does not invalidate the LTFRP, because this law doesn't assert that the rate of profit must fall, come what may. It explains why it does fall, when this happens.

According to Heinrich, "Marx assumes that the fall in the rate of profit, derived as a law, in the long term outweighs all counteracting factors. Yet Marx does not offer a reason for this." However, the reason is simple and obvious: the fall in the rate of profit "was considered an empirically confirmed fact." If it is indeed a fact, and if Marx's law explains it correctly, then it must be the case that the tendency for the rate of profit to fall has in the long run outweighed the counteracting factors. In the same manner, the current (quantum-mechanical) laws of physics are probabilistic, and therefore do not rule out the possibility that a coin flipped into the air will float away instead of falling to the ground. But if it does fall to the ground, and if the laws of physics are correct, then it must be the case that the attractive force of gravity has outweighed all counteracting factors.

C. As we saw above, Heinrich would accept that the LTFRP has been proven only if it has been shown that the rate of profit must fall in the long run, under all circumstances, as a result of accumulation and labour-saving technical change. He contends (in footnote 30 ) that the "proofs" (in his sense) of the LTFRP "either rest upon logical errors ... or upon absurd assumptions, such as the precondition that $\mathrm{v}=0$, as in the work of Andrew Kliman, Reclaiming Marx's "Capital': A Refutation of the Myth of Inconsistency (Lanham: Lexington, 2007)."

Unfortunately, Marx cannot say "Heinrich has seriously misrepresented my argument," since he is dead, but it is fortunate that Kliman can say this, since he is alive and one of the authors of this response. He did not attempt to prove that the rate of profit must fall. His demonstration, like all others put forward by proponents of the temporal single-system interpretation of Marx's value theory (TSSI) is a disproof of "Okishio's theorem" (e.g., Freeman 1996, Potts 2009), which claims that the rate of profit cannot fall under certain conditions. Thus, Kliman's proof consists of the demonstration that it can fall:

As I shall show in the fourth section, a tendential fall in the rate of profit becomes possible, indeed plausible.

We shall see that, when value is determined by labour-time and capital value is not spirited away by means of simultaneous valuation, it follows naturally, indeed inescapably, that labor-saving technological progress can cause the rate of profit to fall. 
Marx's premise that the amount of new value created is determined by labor-time leads naturally, indeed inescapably, to the conclusion that labor-saving technological progress can cause the rate of profit to fall. [Kliman 2007, p. 115, p. 127, p. 128, emphases added]

Heinrich does not refer to the heated dispute around Okishio's theorem. This enables him to refrain from acknowledging openly that the theorem has been disproved. Yet he acknowledges this tacitly when he tries to demonstrate that the LTFRP cannot be proved, since such a demonstration would be superfluous and pointless if the theorem-which was alleged to have disproved the LTFRP - were true.

The assumption that variable capital (v) equals zero was made as part of a refutation of Okishio's theorem, that is, in order to prove that Marx's law is logically possible. In this context, it is not at all absurd. A purported theorem such as Okishio's is disproved if any counterexample is exhibited that produces a conclusion that contradicts the purported theorem without violating any of its stated assumptions. Since $v=0$ doesn't violate any of them, but Kliman exhibited a conclusion that contradicts Okishio's theorem, the purported theorem was disproved.

Heinrich is equally wrong to allege that this assumption was a "precondition," something needed in order for the disproof to succeed. As Kliman (2007, p. 121) made clear, it was merely a simplifying assumption: "The Okishio theorem can be, and has been, disproved without" it. And in an endnote accompanying this remark, he cited two other disproofs of Okishio's theorem which "assume that workers" ... consumption is positive," i.e., that $v>0$. Heinrich refrains from informing the reader about any of this.

Someone who can't interpret what Kliman wrote--in a published book-even remotely correctly has no business trying to interpret what a more subtle thinker like Marx wrote in unpublished draft manuscripts. The conclusions that Heinrich draws from manuscripts to which few others have access, and which they therefore cannot check against the original texts themselves, should not be accepted simply on his say-so.

\section{The "Law as Such," Increases in the Rate of Surplus-Value, and their Limited Effect}

A. Heinrich makes a second major mistake when he claims that Marx included increases in the rate of surplus-value in the "law as such" instead of considering them separately as counteracting factors to the LTFRP. This claim is the lynchpin of his effort to demonstrate that the law as such (i.e., the LTFRP considered in abstraction from counteracting factors) was not proven by Marx and cannot be proven."

Heinrich puts forward the following three-step argument:

(a) "[T]he increase in the rate of surplus-value as a result of an increase in productivity is not one of the 'counteracting factors' [to the LTFRP], but is rather one of the conditions under which the law as such is supposed to be derived." But 
(b) Marx failed to prove that, if rising productivity causes the rate of surplus-value to rise, then the rate of profit must always fall, in every case. "When Marx claims a fall in the rate of profit, then he must demonstrate that in the long term the denominator grows faster than the numerator." "[T] rapidly — and we do not know that. For that reason, at the general level at which Marx argues, nothing can be said concerning long-term tendencies of the rate of profit." Hence,

(c) Marx failed to prove the law as such: "[t]he "law of the tendency of the rate of profit to fall' does not first fall apart in the face of the 'counteracting factors'; it already falls apart because the 'law as such' cannot be substantiated."6

Clearly, this whole line of argument stands or falls with the initial premise that "the increase in the rate of surplus-value as a result of an increase in productivity is not one of the "counteracting factors." Heinrich recognizes that Marx does include a rising rate of surplus-value among the counteracting factors, but he argues (in footnote 28) that Marx was referring only to increases in the rate of surplus-value caused by "the prolongation of the working day and the intensification of labour," not those caused by "the deployment of machinery" and the resulting increases in productivity. This reading is simply a misreading. In the same paragraph of the section "More Intense Exploitation of Labour" that deals with prolongation of the working day and increasing intensity of labour, Marx (1991a, p. 340, emphases added) writes,

It has already been shown, moreover, ... that the procedures for producing relative surplus-value are based, by and large, either on transforming as much as possible of a given amount of labour into surplus-value or on spending as little as possible labour in general in relation to the capital advanced; so that the same reasons that permit the level of exploitation of labour to increase make it impossible to exploit as much labour as before with the same total capital. These are the counteracting tendencies which, while they act to bring about a rise in the rate of surplus-value, simultaneously lead to a fall in the mass of surplus-value produced by a given capital, hence a fall in the rate of profit.

Thus the production of relative surplus-value-i.e., increases in the rate of surplus-value due to the deployment of machinery and the resulting increases in productivity - is indeed one of the counteracting factors, contrary to what Heinrich asserts. His challenge to "the law as such" therefore fails.

In support of his contention that an increase in the rate of surplus-value caused by rising productivity is not among the counteracting factors to the LTFRP, Heinrich also claims to have found a passage in volume 3 of Capital that emphases this supposed fact. "For that reason, shortly after the introductory example Marx emphasizes that the rate of profit also falls in the case of a rising rate of surplus-value." Yet he fails to provide a citation, and there is only one passage that comes shortly after the introductory example that seems vaguely similar to what Heinrich claims. It reads,

With the progressive decline in the variable capital in relation to the constant capital, this tendency leads to a rising organic composition of the total capital, and the direct result of this is that the rate of surplus-value, with the level of exploitation of labour remaining the 
same or even rising, is expressed in a steadily falling general rate of profit. (We shall show later on why this fall does not present itself in such an absolute form, but rather more in the tendency to a progressive fall.) [Marx 1991a, p. 318-9]

This is certainly not a case in which "Marx emphasizes that the rate of profit also falls in the case of a rising rate of surplus-value." Marx's phrase "or even rising" is an aside in a sentence about something else, the effect of a rising organic composition of capital on the rate of profit. More importantly, the sentence provides no support whatever for Heinrich's claim that the "reason" why Marx added "or even rising" was to emphasize that an increase in the rate of surplus-value caused by rising productivity is not a counteracting factor.

It is true that increases in the rate of surplus-value due to production of relative surplus-value have the same cause (labour-saving technical change) as the rise in the value composition of capital that tends to reduce the rate of profit. When different tendencies have a common cause, many theorists refrain from considering them separately. However, the fact remains that Marx did consider them separately. And given this fact, "the law as such" is unexceptionable.

B. In a paragraph quoted in the preceding subsection, Marx notes that increases in the rate of surplus-value have only a limited effect in offsetting the tendency of the rate of profit to fall: "the counteracting tendencies which ... act to bring about a rise in the rate of surplus-value, simultaneously lead to a fall in the mass of surplus-value produced by a given capital, hence a fall in the rate of profit." We can illustrate this point numerically in an extremely simple way.

Let us suppose that, in a given year, a nation's advanced (invested) capital is 100 and the value added by labour in each year is 10, measured in some suitable unit such as trillions of dollars or millions of labour-years. ${ }^{7}$ Let us further suppose that the rate of surplus-value is $100 \%$, so that variable capital (wages) and surplus-value (profit) both equal 5. The actual rate of profit is then $5 / 100=5 \%$. However, the rate of profit could be increased by exploiting labour more. What, then, is the maximum rate of profit that could be achieved? Clearly, $10 \%$, which would occur if no wages were paid at all, and the whole value added of 10 accrued to the capitalists as profit. Pace Heinrich, this fact does not mean that one must suppose no wages are paid, in order to deduce the "law as such." It simply means, in mathematical terms, that the extent to which the law can be overcome by increasing the rate of exploitation has an upper bound. The rate of profit cannot possibly rise above $10 \%$.

Now suppose that, in the course of accumulation, the number of workers employed per 100 units of advanced capital, and thus the value added by labour, falls from 10 to 5. If the rate of surplusvalue remains unchanged at $100 \%$, then wages and profit each fall from 5 to 2.5 and the actual rate of profit falls to $2.5 / 100=2.5 \%$. This fall can again be offset by a rising rate of surplusvalue-but just barely. The maximum possible rate of profit is now 5/100 $=5 \%$. The best that can be achieved by raising the rate of exploitation is to get back to the status quo ante.

And if the number of workers employed per 100 units of advanced capital now falls to 4, no possible increase in the rate of exploitation can restore it. The maximum possible rate of profit falls to $4 / 100=4 \%$. 
Appealing to the simple mathematical relations we have just discussed, Marx (1991a, p. 356) argues that

[t]wo workers working for 12 hours a day could not surplus the same surplus-value as 24 workers each working 2 hours, even if they were able to live on air .... In this connection, therefore, the compensation of the reduced number of workers by a rise in the level of exploitation of labour has certain limits that cannot be overstepped; this can certainly check the fall in the profit rate, but cannot cancel it out.

In other words, if the number of workers employed per unit of advanced capital falls, a rise in the rate of surplus-value can offset the tendency for the rate of profit to fall only to limited extent, as we have just illustrated.

However, Heinrich rejects this simple argument, objecting that Marx failed to prove that the denominator of the rate of profit, advanced capital, will not fall even more sharply than the surplus-value in the numerator. Marx's conclusion "is only correct if the capital (c + v) necessary to employ the two workers is of an amount at least as great as that required to employ twentyfour workers before."

But if the advanced capital, $\mathrm{c}+\mathrm{v}$, needed to employ the two workers is not as great as the advanced capital that was formerly needed to employ twenty-four workers, accumulation has gone into reverse. In order to "prove" that falling employment of labour can always be offset by an increase in the rate of surplus-value, and that the rate of profit can therefore always rise, Heinrich presumes and has to presume the dis-accumulation of capital. ${ }^{8}$

However, the LTFRP presupposes an increase in the denominator of the rate of profit, i.e. the accumulation of capital (see, e.g., Marx 1991a, pp. 324-6). Throughout his discussion of the law, Marx is inquiring into the effects of accumulation of capital that has a labour-saving "bias." Heinrich thus "refutes" the conclusion of Marx's argument by presuming the absence of one of its key premises. This procedure is clearly logically invalid.

\section{The Theoretical Completeness of Marx's Crisis Theory}

Heinrich repeatedly argues that Marx had doubts about whether the LTFRP is correct, and that he might well have abandoned it had he lived longer. These alleged doubts are the key basis on which rest the repeated suggestions (by Heinrich and by the editors of Monthly Review) that Marx's theory of capitalist crisis was unfinished in a theoretically relevant sense-that is, never more than provisional-and more or less in continual flux. ${ }^{9}$ We shall first consider the evidence that Heinrich puts forward, and then turn to other evidence, which he fails to discuss, that Marx was indeed convinced of the correctness of the LTFRP and that he regarded his crisis theory as finished (in a theoretical sense).

A. Heinrich writes, "Already in the Manuscript of 1863-1865, Marx was not completely convinced with his explanation, as is made clear by the repeated attempts at formulating a justification" of the LTFRP. However, he provides no evidence or argument that Marx had 
difficulty formulating a justification of the law. It seems to us that a reasonable case can be made that Marx had difficulty in developing a publishable presentation of the LTFRP, and thus made repeated attempts to do so, but that is a very different matter.

"Marx's" doubts about this law are not present in his texts themselves. Their actual source is the fact that Heinrich utterly fails to understand the purpose and function of the LTFRP, as we discussed in Section II. He writes,

When Marx claims a fall in the rate of profit, then he must demonstrate that in the long term the denominator grows faster than the numerator. Yet there is no evidence whatsoever for such a comparison in the speed of growth. Marx circles around this problem in the text more than he actually delivers any substantiation. His uncertainty becomes clear every time he asserts that the law has been proven, only to once again begin with an argument for it.

[Marx's] doubts were probably amplified in the course of the 1870s. In 1875, a comprehensive manuscript emerges ... [in which] Marx makes note of possibilities for the rate of profit to increase, although the value-composition of capital was increasing. In the case of a renewed composition of book III, all of these considerations would have had to find their way into a revision of the chapter on the "Law of the Tendency of the Rate of Profit to Fall." A consistent regard for them should have led to the abandonment of the "law."

Heinrich is simply misreading the texts in light of his incorrect belief that Marx tried to prove that the rate of profit must fall, under all circumstances. In light of that incorrect belief, every statement by Marx that the rate of profit does not necessarily fall appears to be an admission of failure and uncertainty. ${ }^{10}$ And Heinrich misconstrues every new attempt to work out a publishable formulation of the LTFRP and every new exploration of its implications as one more effort to prove that the rate of profit must fall.

The best evidence that Heinrich's interpretation is seriously incorrect is the fact that Marx repeatedly asserts that the law has been proven, even though he also repeatedly notes that counteracting factors can outweigh the tendency for the rate of profit to fall, causing the rate of profit to rise. On Heinrich's reading, these two sets of passages fail to cohere with one another. However, an accepted principle of interpretation known as the "criterion of coherence" or "principle of charity" says that we should reject a reading on which the text fails to cohere in favor of one that produces coherence among the texts. "[T] he adequacy of a given textual interpretation depends on the extent to which it can show the text's coherence as a- unified whole" (Warnke 1993, p. 21).

Heinrich's interpretation utterly fails to satisfy this criterion. But in keeping with the whole Marxism without Marx tradition, he blames his own failure on Marx. ${ }^{11}$ Heinrich should have accepted that his interpretation fails to make the texts cohere, and he should have searched for a more successful interpretation. Instead, he wrongly charges that it is Marx's text rather than his own interpretation that fails the test of coherence. 
B. One crucial kind of evidence that Marx was indeed completely convinced that the LTFRP is correct is the fact that he repeatedly "assert[ed] that the law has been proven." This is a fact that Heinrich concedes; indeed, these are his own words.

In addition, there is considerable evidence in Marx's correspondence-spanning the period from 1865 to 1877 - that he was satisfied with his theoretical results and that he regarded Capital, not only the first volume that he published but also the volumes that remained unpublished, as a finished product in a theoretical sense.

On July 31,1865 , he wrote to Frederick Engels that

[t]here are 3 more chapters to be written to complete the theoretical part (the first 3 books). Then there is still the 4th book, the historical-literary one, to be written, which will, comparatively speaking, be the easiest part for me, since all the problems have been resolved in the first 3 books, so that this last one is more by way of repetition in historical form. But I cannot bring myself to send anything off until I have the whole thing in front of me. WHATEVER SHORTCOMINGS THEY MAY HAVE, the advantage of my writings is that they are an artistic whole, and this can only be achieved through my practice of never having things printed until I have them in front of me in their entirety. [Marx 1987, $\mathrm{p}$. 173. Phrases emphasized by us are in italics; the phrase in boldface was emphasized by Marx. The phrase in small caps was written in English.]

This letter indicates that Marx had resolved, to his satisfaction, all of the theoretical problems he had confronted (note the phrase "have been resolved"). It further indicates that he would not allow volume 1 of Capital to be published until the whole of Capital was complete in a theoretical sense. Thus, the publication of volume 1 a couple of years later is further evidence that Marx regarded the whole of Capital as complete and satisfactory in a theoretical sense.

On February 13, 1866, he wrote to Engels that

[a]s far as this "damned" book is concerned, the position now is: it was ready at the end of December. The treatise on ground rent alone, the penultimate chapter, is in its present form almost long enough to be a book in itself. ...

Although ready, the manuscript, which in its present form is gigantic, is not fit for publishing for anyone but myself, not even for you.

... I began the business of copying out and polishing the style on the dot of January first, .... [Marx 1987, p. 227, emphases in original]

The book that Marx says was ready at the end of 1865 is not volume 1 of Capital (or not it alone), since the "treatise on ground rent" is part of what became volume 3, the volume that contains Marx's LTFRP and the crisis theory based on it. The whole of Capital is said by the author to have been ready, or finished, as of the end of 1865 . Note also that the distinction between being ready in a theoretical sense and ready in the sense of stylistically polished and "fit 
for publishing" is not ours, but Marx's. The letter indicates that he regarded it as ready in the former sense even though it was not ready in the latter.

On April 30, 1867, Marx (1987, pp. 366-7) wrote to Sigrid Mayer that

I should really have thought myself unpractical if I had pegged out [died] without finally completing my book, at least in manuscript.

The first volume of the book will be published by Otto Meissner in Hamburg in a few weeks.

... I hope that a year from now the whole work will have appeared. Volume II contains the continuation and conclusion of the theory, Volume III the history of political economy from the middle of the 17 th century. ${ }^{12}$

Once again, Marx indicates that he has "finally complet[ed]" the whole of Capital, even though only volume 1 will soon appear. And he further indicates that he hoped to be able to publish the remaining volumes within a year. That is not something he could have realistically hoped for if he had any doubt about their completeness in a theoretical sense.

Finally, on November 3, 1877, Marx (1991b, p. 287) wrote to Sigmund Schott that

I began by writing Capital in a sequence (starting with the $3^{\text {rd }}$, historical section) quite the reverse of that in which it was presented to the public, saving only that the first volumethe last I tackled-was got ready for the press straight away, whereas the two others remained in the rough form which all research originally assumes.

This suggests, yet again, that Marx regarded himself as having completed volume 3 of Capital before writing volume 1 , although it was complete only in the theoretical sense, not in terms of form, which "remained ... rough."

This was not Marx's view alone. In his Preface to volume 3 of Capital, Engels, who edited the book, complained about the often considerable difficulties he faced when turning the manuscripts that Marx left into a publishable volume. For instance, the manuscript of what became part 5, which deals with the division of profit into interest and "profit of enterprise," was only "the beginning of an elaboration which petered out more than once in a disordered jumble of notes, comments and extract material" (Engels 1991, pp. 94-5). In marked contrast to this, the manuscript of what became part 3, on the LTFRP and the theory of crisis based on it, were such that "I was able to keep almost completely to the original manuscript, apart from stylistic editing" (Engels 1991, p. 94, emphasis added).

Heinrich's article may seem to call Engels' evaluation into question, but a careful reading indicates that it does not. Heinrich tells us that it was Engels, not Marx, who divided part 3 into chapters. He also tells us that Engels gave the final chapter of part 3 (in which Marx discussed the relationship between the internal contradictions of the LTFRP and economic crisis) a title, and that "he condensed it with abridgments, he made rearrangements, and divided it into four 
subsections." Quite so. This is what a good editor does. It is called what Engels called itstylistic editing.

As much as Heinrich may wish us to believe that this chapter is a "construct[ion]" of Engels', who "heavily revised" Marx's manuscript, ${ }^{13}$ the fact is that he provides no evidence whatsoever that the "already largely completed theory of crisis" that emerged from Engels" stylistic editing is Engels" theory rather than Marx's own. When one condenses, abridges, rearranges, etc., one does not create a theory that was not already there to begin with. One simply makes the theory that is already there more perspicuous. ${ }^{14}$ And that is Heinrich's real gripe against Engels' editing. He carried out Marx's request to make something of his unpublished manuscript, while Heinrich wants to unmake it. The clear purpose of this attempted unmaking is to eliminate Marx's own crisis theory from consideration and thereby enable an alternative "Marx"ist theory to take its place, instead of frankly acknowledging that Marx's theory exists and allowing it to contend with the alternative one.

Yet even if it were true that the crisis theory of the third volume of Capital is Engels" rather than Marx's —or, indeed, our own "construction"- - that would not matter at all from a scientific (wissenschaftlich) perspective. It would not matter even if Marx himself might ultimately have come to repudiate it had he lived long enough, as Heinrich suggests. ${ }^{15}$ The fact remains that this crisis theory exists. And it is entitled to contend with the alternatives and to be assessed against them on the basis of relative explanatory power, not eliminated and not ignored on the grounds that, as Heinrich's editors put it, "Marx never ceased to develop his thinking on the phenomena of crises in capitalism, and never ceased to discard earlier formulations."

\section{References}

Baran, Paul A. and Paul M. Sweezy. 1966. Monopoly Capital: An essay on the American economic and social order. New York: Monthly Review Press.

Colander, David, Hans Föllmer, Armin Haas, Michael Goldberg, Katarina Juselius, Alan Kirman, Thomas Lux, and Brigitte Sloth. 2009. "The Financial Crisis and the Systemic Failure of Academic Economics.” Kiel Working Paper 1489, Kiel Institute for the World Economy, Feb.

Duménil, Gérard and Dominique Lévy. 2004. Capital Resurgent: Roots of the neoliberal revolution. Cambridge, MA: Harvard University Press. . 2011. The Crisis of Neoliberalism. Cambridge, MA: Harvard University Press.

Engels, Frederick. 1991. "Preface.” In: Marx, Karl, 1991a. Capital: A critique of political economy, Vol. III. London: Penguin.

Freeman, Alan. 1996. “A General Refutation of Okishio's Theorem and a Proof of the Falling Rate of Profit." In: Freeman, Alan and Guglielmo Carchedi (eds.), Marx and Nonequilibrium Economics, Aldershot, UK: Edward Elgar. 
. 2009. "Investing in Civilization.” In: Guard, Julie and Wayne Antony (eds.),

Bankruptcies and Bailouts, Black Point, CA: Fernwood Publishing.

2010. “Marxism Without Marx: A note towards a critique," Capital and Class 34:1, pp. 84-97.

. 2012. "What Causes Booms?" Proceedings of the International Conference on "Marx and Beyond," Kolkata, India, Mar.

. 2012/13. "The Profit Rate in the Presence of Financial Markets: A necessary correction," Journal of Australian Political Economy 70, Summer.

Freeman, Alan and Andrew Kliman. 2008. "Simultaneous Valuation vs. the Exploitation Theory of Profit: A summing up," Capital and Class, No. 94, Spring, pp. 107-17.

Hegel, Georg Wilhelm Friedrich. 1991. The Encyclopedia Logic, T. F. Geraets, W. A Suchting, and H. S. Harris (eds.). Indianapolis: Hackett Pub.

Heinrich, Michael. 2013. "Crisis Theory, the Law of the Tendency of the Profit Rate to Fall, and Marx's Studies in the 1870s," Monthly Review 64:11, April. Available at monthlyreview.org/2013/04/01/crisis-theory-the-law-of-the-tendency-of-the-profit-rateto-fall-and-marxs-studies-in-the-1870s.

Kliman, Andrew. 2007. Reclaiming Marx's "Capital”: A refutation of the myth of inconsistency. Lanham, MD: Lexington Books.

. 2012. The Failure of Capitalist Production: Underlying causes of the Great Recession. London: Pluto Books.

Marx, Karl. 1987. Karl Marx, Frederick Engels: Collected Works, Vol. 42. New York: International Publishers.

1990. Capital: A critique of political economy, Vol. I. London: Penguin.

. 1991a. Capital: A critique of political economy, Vol. III. London: Penguin.

1991b. Karl Marx, Frederick Engels: Collected Works, Vol. 45. New York: International Publishers.

Monthly Review editors. 2013. [Introduction to Heinrich, Michael, "Crisis Theory, the Law of the Tendency of the Profit Rate to Fall, and Marx's Studies in the 1870s"], Monthly Review 64:11, April. Available at monthlyreview.org/2013/04/01/crisis-theory-the-law-of-thetendency-of-the-profit-rate-to-fall-and-marxs-studies-in-the-1870s.

Potts, Nick. 2009. “Trying to Help Rescue Value for Everyone,” Critique: Journal of Socialist Theory 37:2, pp. 177-99. 
. 2011a. "Marx and the crisis," Capital \& Class 35:3, pp. 455-74.

. 2011b. "Valuation in the Presence of Stocks of Commodities," Critique of Political

Economy 1, pp. 89-119.)

. 2012. "Unforgivable Misrepresentation: Deliberately Distorting the Temporal Single

System Interpretation of Marx in Order to Dismiss Marx's Value Theory." Presented to the Joint Conference of the Association for Heterodox Economics, the International Initiative for Promoting Political Economy and the French Association for Political Economics, Paris, July.

. "Keynesian Economics: In search of unnatural stability," Critique: Journal of Socialist Theory, forthcoming.

Ramos-Martínez, Alejandro. 2004. "Labour, Money, Labour-Saving Innovation, and the Falling Rate of Profit." In: Freeman, Alan, Andrew Kliman, and Julian Wells (eds.), The New Value Controversy and the Foundations of Economics, Cheltenham, UK: Edward Elgar.

Romer, David. 2011. "What Have We Learned about Fiscal Policy from the Crisis?,” Sept. 2011 version. Available at http://elsa.berkeley.edu/ dromer/.

Warnke, Georgia. 1993. Justice and Interpretation. Cambridge: MIT Press.

\section{Notes}

${ }^{1}$ See for example, the collection by Colander et al. (2009), and Romer (2011, pp. 1-2), who writes, "We thought we had macroeconomic fluctuations well under control, but they are back with a vengeance. ... The workhorse new Keynesian dynamic stochastic general equilibrium (DSGE) models on which we were concentrating so much of our attention have been of minimal value in addressing the greatest macroeconomic crisis in three-quarters of a century." See Potts (2013) for a critique of Keynesian explanations of the latest economic crisis, Kliman (2012) for an alternative empirical account rooted in Marx's theory, and Freeman (2009) for an early and correct prediction of the length and depth of the crisis in the No-Longer-Developing ("advanced") countries, rooted in Marx's theory of the causes of the falling rate of profit and the circumstances in which it is reversed.

2 This crisis theory does not counterpose the fall in the rate of profit to credit-market disturbances and other kinds of financial instability, nor does it privilege the former over the latter. Financial instability is a crucial link between the LTFRP and economic crises, as Marx emphasizes throughout much of the final chapter on the LTFRP in Capital, volume 3. The following statements (by Heinrich and the editors of Monthly Review, respectively) wrongly try to counterpose the LTFRP and financial instability: "a systematic treatment of crisis theory is not possible on the immediate basis of the law of the tendential fall in the rate of profit (as suggested by Engels's edition of the third volume of Capital), but rather only after a presentation of interest-bearing capital and credit" (emphasis in original). "Marx ... never ceased to discard 
earlier formulations; for example, at the end of his life he was focused on questions of credit and crisis." For a discussion of the empirical trend in the rate of profit that takes financial investment into account, see Freeman (2012/13).

${ }^{3}$ Here and below, quotations not accompanied by citation information quote Heinrich's article.

${ }^{4}$ In order to answer Heinrich, it is unnecessary to discuss the precise meaning of "long run" ("auf die Dauer") in this context. We do however emphasize that there no textual support for the assertion, sometimes attributed to Marx, that he claimed the rate of profit would exhibit a declining trend throughout the whole history of capitalism. In particular this is incompatible with Marx's view that the destruction of capital value through crises repeatedly cancels the effect of the tendency for the rate of profit to decline. See Potts (2011), Kliman (2012, pp. 25-6), and Freeman (2012) for further discussion.

${ }^{5}$ It is crucial to understand what "not proven" means in this context: cases in which the numerator of the rate of profit rises in relation to the denominator cannot be ruled out on the basis of the laws of mathematics and logic alone. No reasonable person has ever thought otherwise.

${ }^{6}$ Heinrich makes an additional argument against the "law as such": "The growth of c[onstant capital], from which the decline in the rate of profit supposedly results, is not completely unlimited. In the second part of the fifteenth chapter of the first volume of Capital, Marx argues that the additional application of constant capital encounters its own limits in the reduction of variable capital. If this is consistently taken into consideration, this presents a further argument against the "law as such." However, Marx's argument is simply that the additional constant capital investment will be undertaken only if it reduces the per-unit cost of production. This requirement does not limit the growth of constant capital. Imagine that the variable capital is $\$ 9$. If the constant capital is $\$ 1$, and 10 widgets are produced, the per-unit cost is $(\$ 9+\$ 1) / 10=\$ 1$. If the constant capital is now increased to $\$ 90$, and this results in the production of 100 widgets instead of 1 , the per-unit cost falls to $\$ 0.99$. If the constant capital is increased again, to $\$ 97,991$, and the number of widgets produced is now 100,000 , the per-unit cost falls to $\$ 0.98$. And so on. ${ }^{7}$ Value can be expressed both in terms of money and in terms of labour-time, and we can move between these two expressions by means of what Ramos-Martinez (2004) has called the monetary expression of labour-time (MELT). For more on the MELT, see Potts (2011); for discussions of how mainstream Marxist economists "misunderstand" it and turn it against the TSSI, see Freeman and Kliman (2008) and especially Potts (2012).

${ }^{8}$ In other words, if the ratio of constant capital to the amount of living labour performed increases without bound and if total capital accumulates without bound, then the rate of profit under discussion (the ratio of surplus-value to total advanced capital) must eventually fall, despite any and all increases in the rate of surplus-value. Heinrich himself tacitly admits this. Note that the rate of profit must eventually fall in this case even if the amount of living labour performed continually increases over time.

${ }^{9}$ The editors write that Marx "never ceased to discard earlier formulations" of his crisis theory and that "the various fragmentary references to crisis theory in ... Capital [do not] constitute a fully developed coherent structure." Heinrich asserts that there is "no final presentation" of Marx's crisis theory, but only "various approaches [at different times] to explain crises," marked by "shifts in the theoretical framework" of Marx's analysis, and only "disparate thoughts on crisis theory" rather than "a unified theory of crisis" even within the text of Capital, volume 3. 
${ }^{10}$ Heinrich also points to a comment that Marx wrote in the margin of his copy of volume 1 of Capital: "Note here for working out later: if the extension [accumulation of capital] is only quantitative [i.e., if constant capital does not increase relative to variable capital], then for a greater and a smaller capital in the same branch of business the profits are as the magnitudes of the capitals advanced. If the quantitative extension induces a qualitative change [i.e., if constant capital increases relative to variable capital], then the rate of profit on the larger capital rises at the same time" (Marx 1990, p. 781 n11, emphasis added). Heinrich claims that Marx "hints" here that he is moving in the direction of abandoning the LTFRP, according to which the rate of profit on the larger capital should (according to Heinrich) fall. However, there are other interpretations that we consider far more plausible. One is that "rises" is merely a slip of the pen, and that Marx meant "falls." Another is that Marx is referring to a case-fully consistent with his value theory and the LTFRP — that he discusses elsewhere (Marx 1990, pp. 433-6; Marx 1991a, pp. 373-4): since the larger capital's ratio of constant to variable capital is greater, it is more productive than the smaller capital in the same branch of business. Consequently, its costs of production are lower and its rate of profit is higher. There are several reasons why Heinrich's interpretation is very implausible. First, the view that labor-saving technical change raises the rate of profit directly contradicts everything else Marx said about the subject. Second, it directly contradicts his value theory as well as his theory that all profit comes from surplus labor. Thus, if Marx were hinting at the abandonment of the LTFRP, he would also be hinting at the abandonment of almost all of Capital. In light of the absence of any evidence that he had any doubts about the theories of value and profit, this is very unlikely. Third, what makes it even more unlikely is Marx's introductory comment, "Note here for working out later." No serious theorist repudiates the very core of his or her theory in such a nonchalant manner. If Heinrich's interpretation were correct, Marx's comment would be equivalent to Galileo writing "Note here for working out later: the earth is stationary" in the margin of his book.

${ }^{11}$ See Kliman (2007, chap. 4 and passim).

${ }^{12}$ What Marx calls "volume II" here are the second and third books of Capital, which were eventually published as volumes 2 and 3, respectively. What he calls "volume III" was eventually published under the title Theories of Surplus-Value.

13 "Engels heavily revised this material to construct the third chapter on the "law."

${ }^{14}$ Condensation, abridgement, and rearrangement can greatly affect the structure of a poem or novel, since their structure depends heavily on the precise order of different pieces of text. In contrast, the structure of a theory does not depend on the relation between pieces of text, but on the relation between ideas. While stylistic editing can make it easier to recognize how the ideas are related, it cannot alter the relations among them or create relations that did not exist in the first place.

${ }^{15}$ Marx might also have gone on to sing "Dancing Queen" while wearing a chicken suit. Or, he might have become a Catholic, a priest, etc. and, finally, the Pope. We have borrowed the latter example from Hegel, who used it to show the puerility of such appeals to mere possibility. "Rational, practical people do not let themselves be impressed by what is possible, precisely because it is only possible; instead, they hold onto what is actual" (Hegel 1991, p. 216, addition to $\S 143$ ). 